\title{
Quality of Amoxycillin Preparations on the Kenyan Market
}

\author{
F. N. KAMAU*, G. N. THOITHI, J. K. NGUGI, O. K. KING'ONDU AND I. O. KIBWAGE
}

Department of Pharmaceutical Chemistry, Faculty of Pharmacy, College of Health Sciences, University of Nairobi, P.O. Box 19676-00202, Nairobi.

\begin{abstract}
Amoxycillin products were evaluated for quality by liquid chromatography at the Drug Analysis and Research Unit (DARU), University of Nairobi. Thirty three of these were capsule formulations and 24 were dry suspensions. Three capsule formulations failed the limits on content. The amoxycillin content in one suspension product was below the limit, while in two other products it dropped below $80 \%$ on storage at $25^{\circ} \mathrm{C}$ for 7 days.
\end{abstract}

Key Words: Amoxycillin, formulations, quality.

\section{INTRODUCTION}

Amoxycillin is a semisynthetic penicillin used in the management of infections caused by sensitive organisms infections especially those causing pneumonia, URTI, UTI and soft tissue infections. It is incorporated in the Ministry of Health essential drugs list [1].

Marketing of poor quality drugs is a major concern in most developing countries and has been widely reported in Africa and elsewhere [2-5]. In particular, the use of antibiotic preparations of poor quality could be a contributory factor to failure of therapy. The presence of poor quality penicillin products in the Kenyan market has been reported previously [6-9]. This observation was recently reinforced by the findings on the quality of ampicillin preparations [10].

This paper reports on the findings on the quality of amoxycillin capsules and dry syrups found on the Kenyan market during the 10 year period 1994 - 2004 using high pressure liquid chromatography (HPLC). The preparations were from private and public sources including those submitted to the Ministry of Health drug regulatory authority, the Pharmacy and Poisons Board. The latter are intended for market in Kenya after registration, and for the purpose of this paper are treated as being on the market.

\section{EXPERIMENTAL}

\section{Samples and standards}

Amoxycillin trihydrate, working standard Batch No. M 1561193 was donated by Laboratory and Allied Ltd., Nairobi. The working standard had a content of $87.0 \%$ amoxycillin on an anhydrous basis when assayed against amoxycillin trihydrate BPCRS Batch No. 1487 CAT. 019.

The amoxycillin preparations evaluated were obtained through the office of Registrar, Pharmacy and Poisons Board, Ministry of Health, Kenya, or were commercial packs obtained from local pharmacies and manufacturers. Locally manufactured products were from Elys Chemical Industries Ltd., Dawa Pharmaceuticals Ltd., Cosmos Ltd., Mac's Pharmaceuticals Lid. and Pharmaceutical Products Ltd., all of Nairobi. Imported products were from Mesco Laboratories Ltd., Cadila Laboratories Ltd., Ranbaxy Laboratories Ltd., Dominion Chemical Industries Ltd., Panacea Biotech Ltd., Rumax Ltd., Lennon Ltd., F. I. R. M. A. Ltd., Brown and Buck Pharmaceutical Ltd.; all of India as well as C.A.P.S. (Zimbabwe), Amoun Pharmaceutical Industries Co. Ltd. (Egypt), Servipharm Ltd., (Switzerland), and Glaxosmithkline (U.K.)

\section{Reagents and solvents}

HPLC grade acetonitrile was purchased from Rathburn chemicals (Walkerburn, Scotland, U.K.). Analytical grade, $\mathrm{K}_{2} \mathrm{HPO}_{4}$ and $\mathrm{KH}_{2} \mathrm{PO}_{4}$ salts for preparation of buffer were from Acros Organics (New Jersey, USA).

\section{Instrumentation}

The liquid chromatographic system consisted of Varian 9010 solvent delivery system, a Varian Variable wavelength UV/Visible detector (Varian Associates, Inc., Walnut Creek, USA) set at $254 \mathrm{~nm}$, a Valco model CV-6-UHPa-N60 
sampling valve (Valco, Houston, Texas, USA) equipped with a $25 \mu l$ loop and a Hewlett Packard HP 3396 integrating recorder (Hewlett Packard, Avondale, PA, U.S.A.). A HPLC column of dimensions $25 \mathrm{~cm} \times 4.6 \mathrm{~mm}$ packed with RSil $\mathrm{C}_{18} 10 \mu \mathrm{m}$ (BioRad RS, Eke, Belgium) was used and was maintained at $40^{\circ} \mathrm{C}$ using a water bath.

\section{METHOD}

\section{Mobile phase}

The mobile phase consisted of $0.01 \mathrm{M}$ phosphate buffer $\mathrm{pH} 7.0$ - acetonitrile (97: 3 $\mathrm{v} / \mathrm{v}$ ) and was degassed by ultrasonication before use. The flow rate was set at $1.0 \mathrm{ml} / \mathrm{min}$.

\section{Amoxycillin standard solution}

About $125 \mathrm{mg}$ amoxycillin standard was accurately weighed into a $10.0 \mathrm{ml}$ volumetric flask, dissolved in, and made to volume with distilled water. An aliquot $(2.0 \mathrm{ml})$ of this solution was diluted to $25.0 \mathrm{ml}$ with distilled water in a volumetric flask.

\section{Amoxycillin sample solution}

Capsules: Powder equivalent to $125 \mathrm{mg}$ amoxycillin accurately weighed was dissolved in distilled water as completely as possible, to make $100.0 \mathrm{ml}$ in a volumetric flask. This solution was filtered though a $0.45 \mathrm{~mm}$ membrane filter and $4.0 \mathrm{ml}$ of the filtrate made to volume with distilled water in a $25.0 \mathrm{ml}$ volumetric flask.

Dry suspensions: Powder for amoxycillin suspensions was reconstituted with distilled water according to the manufacturer's label instructions. The reconstituted volume of the suspension was determined after sonication to remove air bubbles. A volume of suspension equivalent to $125 \mathrm{mg}$ amoxycillin was pipetted into a $100.0 \mathrm{ml}$ volumetric flask, rinsing the pipette with water. The volume was made to the mark with water and filtered through a $0.45 \mathrm{~mm}$ membrane filter. An aliquot $(4.0 \mathrm{ml})$ of the filtrate was used to prepare the sample solution as described for the standard solution.

\section{RESULTS AND DISCUSSION}

The content of active ingredient of some 33 amoxycillin capsule formulations were evaluated and are shown in Table 1. The pharmacopoeal limits [11] of amoxycillin content expressed as a percentage of label claim are $92.5-110.0$. Products Ia, III and VI failed in this test. All the failed products were manufactured locally. The failed product la was by a manufacturer whose other product batch $\mathrm{Ib}$ passes in the test.

Table 1: Amoxycillin Content of Some Amoxycillin Capsule Products

\begin{tabular}{cc}
\hline Product & $\begin{array}{c}\text { Amoxycillin content } \\
\text { (\% label claim) }\end{array}$ \\
\hline I a & 90.4 \\
I b & $10 \%$ \\
II & 108.0 \\
III & 75.6 \\
Va & 100.7 \\
IVb & 93.3 \\
Va & 94.4 \\
Vb & 93.0 \\
Vc & 94.7 \\
Vd & 96.0 \\
Ve & 95.5 \\
VI & 79.2 \\
VII & 96.7 \\
VIIIa & 96.0 \\
VIIIb & 100.6 \\
IX & 108.4 \\
X & 104.6 \\
XIa & 103.0 \\
XIb & 101.6 \\
XIIa & 95.6 \\
XIIb & 93.8 \\
XIIIa & 108.3 \\
XIIIb & 108.3 \\
XIVa & 106.8 \\
XIVb & 101.8 \\
XVa & 99.6 \\
XVb & 96.9 \\
XVI & 101.6 \\
XVIIa & 96.9 \\
XVIIb & 96.9 \\
XVIIc & 95.2 \\
XVIII & 98.3 \\
XIX & 100.3 \\
\hline & \\
\hline & \\
\hline
\end{tabular}

?- XVII denote manufacturers; $a, b, c, d$ and e: indicate batches from the same manufacturer. 
Table 2 shows the amoxycillin content as determined on day 0 and day 7 for the 24 different amoxycillin suspensions examined. One product, SVII was far below the lower limit of $80 \%$ specified by the pharmacopoeia. On storage for 7 days at $25^{\circ} \mathrm{C}$ the amoxycillin content of SXb and SXla fell below the acceptable limit of $80 \%$. The content of SX la fell drastically from $107.8 \%$ to $44.1 \%$ of the label claim. The content of amoxycillin in all the products examined changed within the 7 days. Amoxycillin suspensions are normally buffered to maintain stability once reconstituted. The products that failed to comply with the 7day limit were probably not appropriately buffered.

Table 2: Amoxycillin Content of Some Amoxycillin Oral Suspensions

\begin{tabular}{lrc}
\hline Product & \multicolumn{2}{c}{$\begin{array}{c}\text { Amoxycillin content } \\
\text { (\% of label claim) }\end{array}$} \\
\hline & Day 0 & Day 7 \\
\hline SIa & 108.0 & $\mathrm{n} \mathrm{d}$ \\
SIb & 94.1 & $\mathrm{nd}$ \\
SIc & 107.6 & 96.6 \\
SId & 109.2 & 96.7 \\
SIia & 107.3 & 114.2 \\
Slib & 114.1 & 126.7 \\
SIII & 114.1 & 112.6 \\
SIVa & 99.3 & 91.6 \\
SIVb & 94.1 & 107.0 \\
SIVc & 99.1 & 103.3 \\
SIVd & 99.5 & 104.9 \\
SIVe & 99.5 & 101.4 \\
SV & 95.0 & $\mathrm{nd}$ \\
SVI & 98.5 & 102.2 \\
SVII & 42.9 & 32.1 \\
SVIII & 83.6 & 80.5 \\
SIX & 97.3 & 86.2 \\
SXa & 96.9 & 85.7 \\
SXb & 84.4 & 67.5 \\
SXia & 107.8 & 44.1 \\
SXib & 99.5 & 96.6 \\
SXII & 98.4 & 102.8 \\
SXIII & 98.1 & $\mathrm{nd}$ \\
SXIV & 95.3 & $\mathrm{nd}$ \\
\hline
\end{tabular}

I - XIII denote manufacturers; $a, b, c, d$ and e: refer to batches from the same manufacturer; $\mathrm{n} d$ : not determined.

The content of amoxycillin in oral suspensions is specified not to exceed $120 \%$ label claim on reconstitution. However, on storage for 7 days, any drop in content should not be lower than $80 \%$ of the label claim (11).
In this regard products SVII, SXb and SXIa failed the requirements. The manufacturers of products $\mathrm{SXb}$ and SXIa are also the manufacturers of products SXa and SXIb respectively, which passed the requirements. One was a local and the other a foreign manufacturer.

There is therefore need for manufacturers to pay attention to such batch to batch variations that may arise and identify causes for them, for example a less than optimum buffering system.

The use of poor quality products, especially antibiotics, such as amoxycillin, can have serious consequences including development of drug resistance and therapeutic failure.

The results of this study support the continuing need for quality certification before and marketing surveillance after products are released into the market by reputable laboratories.

\section{ACKNOWLEDGEMENT}

The authors acknowledge financial support from the Belgian Government (VLIR-ABOS Grant No. JH107).

\section{REFERENCES}

[1] Kenya Essential Drugs List 2003, Ministry of Health, Government of Kenya

[2] M. Murtada and B. Sesay, Int. Pharm. J. 8 (1994) 202.

[3] I.O. Abu - Reid, S.A. El - Samani and A.I. Hag Omer, Int. Pharm. J. 4 (1990) 6.

[4] P. Dennis, L.A. Edghill, M. Allen and Y.B. Acheampong, Int. Pharm. J. 6 (1992) 64

[5] I.O. Kibwage, J.O. Ogeto, C.K. Maitai, G. Rutere, J.K. Thuranira and J. Ochieng. E. Afr. Med. J. 69 (1992) 577.

[6] C.K. Maitai, W.M. Kofi - Tsekpo, E. Wakori, C. Wangia, L. Mkoji and I. .M. Githiga, E. Afr. Med. J. 59 (1982) 399. 
[7] J.O. Ogeto, C.K. Maitai, C. Wangia, M.L. Mkoji, E. Wakori, G.K. Rutere, R.W. Muthama, A. Ochieng and I.M. Githiga. E. Afri. Med. J. 60 (1998): 438.

[8] K.O. Mangera, G.K. Rutere, J.K. Thuranira, R. Mithamo, A. Ochieng, S. Vugigi, E.M. Ogaja and I.O. Kibwage. Pharm. J. Kenya. 4 (1993) 66.
[9] I.O. Kibwage and S. Vugigi. Pharmacother. Drug Infor. Bull. 1, (1991) 6.

[10] F.N. Kamau, G.N. Thoithi and I.O. Kibwage. East Cent. Afr. J. Pharm. Sci. 4 (2001) 25.

[11] British Pharmacopoeia 2000 Vol. II H M SO. 